New move confuses

US patents world

Washington

PATENT attorneys are complaining of "total chaos" over what is required in filing a genetic engineering patent in the wake of a surprise decision by the US Patent and Trademark Office to drop its earlier objections to the second Cohen-Boyer patent application, which covers basic processes in genetic engineering.

The patent office's decision, which was transmitted to Stanford University (which, along with the University of California, holds rights to the patent) on 21 January, was not announced, in keeping with Stanford's request last December to close public access to the patent proceedings. Kathy Ku of Stanford's Office of Technology Licensing confirmed, however, that the patent office had dropped its two principal earlier objections, while raising one new objection. She refused to elaborate.

The confusion centres on what an application must do to meet the patent law's disclosure requirement that a patent must provide enough detail to allow a person with "ordinary skill in the art" to duplicate the invention. Fred Whisenhunt of the Washington firm Murray \& Whisenhunt explains that "The bar in general has concluded from the practice of the patent of fice that when you have a new organism, the only way to have a complete disclosure is to deposit that organism in a public depository".

Depositories such as the American Type Culture Collection are commonly used for this purpose. The patent office's decision in the Cohen-Boyer case, however, has cast a cloud of doubt over this assumption. "According to a lot of members of the bar," Whisenhunt said, "it is a substantial departure from past practice and leaves unanswered what is acceptable."

"The bar is confused", said another attorney familiar with the case. "It's not fair that some people are playing it strictly by the rules and other people are getting away with murder. What is needed are some guidelines - and promptly."

The unusual facts of the Cohen-Boyer case have brought the disclosure issue into sharp focus. The patent application covers the basic process for inserting foreign DNA into bacterial plasmids. Trouble for the patent began last summer, when the patent of fice became aware that the recipe set out in the application for making pSC101 the plasmid used to carry the foreign DNA - was incorrect; this raised the possibility that a person with "ordinary skill" would not, in fact, be able to reproduce Cohen's and Boyer's work by following the disclosure in the patent.

But Stanford had a fall-back argument.
The plasmid, they said, was made readily available by Cohen to anyone who requested it, subject only to some safety guidelines and a request that it should not be passed on to others. Thus the plasmid was publicly available at the time the application was filed - and the application need not therefore disclose how to make it.

By dropping its objections, the patent office apparently accepted this claim much to the surprise and consternation of many patent attorneys, who argue that a private collection maintained by the inventors is no substitute for a public depository. "Based upon what we know, we really think the patent office made a mistake", said Barry Bretschneider of Wegner \& Bretschneider, although he emphasized that the full implications of the patent office's action will not be known until the details of the decision are made public.

Whisenhunt says that there are no assurances that a specimen in a private collection will continue to be available to the public. "Another concern is that when you deposit in a public depository you can always determine the characteristics of the organism at the date of filing" - while a sample in a private collection may be replaced with subsequent versions over the years, thus obscuring the true record of what the patent actually covers. "There are members of the bar who feel this is fraught with dangers", he said.
While confusion persists, there is no agreement about the best way of reforming the patent office's procedures. Bretschneider, for one, is doubtful that the problem could be solved by the patent office drawing up strict guidelines, as has been done in Japan. "I'm not confident that our patent office has the experience to issue guidelines that would be applicable in all cases, and I think they understand that."

Meanwhile, the Cohen-Boyer patent may be headed for more trouble. In addition to the new objection raised by the patent office, evidence has come to light of a prior publication that may bring into question the novelty and originality of Cohen's and Boyer's work as defined by the patent law. The publication was a PhD thesis by Stanford graduate student, Peter Lobban, which sets out the complete conceptual framework of the recombinant DNA process.

Although Cohen was the first to do the actual laboratory experiments, the thesis - dated May 1972, more than a year before the Cohen and Boyer publication could defeat the patent application if it could be held to have made the subsequent work "obvious". The American Patent Law Association's Chemical Practice Committee has a programme of collecting publications relating to genetic engineering and supplying these to the patent office; the Lobban thesis was forwarded to the patent office by this group on 2 March. Several patent attorneys who represent licensees or potential licensees of the Cohen-Boyer patent are thought to have been dismayed at this development on the grounds that they have been hoping to keep the Lobban thesis as ammunition for litigation against the patent after it had been issued.

Stephen Budiansky

\title{
Cancer incidence in England and Wales
}

TAKEN from the recently-published 1978 cancer statistics for England and Wales, the figure shows the percentage increase in incidence of cancer of each five-year age group over the previous one, excluding the age groups 0 to 10 , which would mask the general trends since there is an uncharacteristically high incidence of cancer in the youngest age group. Both males and females show a sudden increase in the number of registrations of cancer, but there is a sex difference in the age at which this occurs, being for females between 25

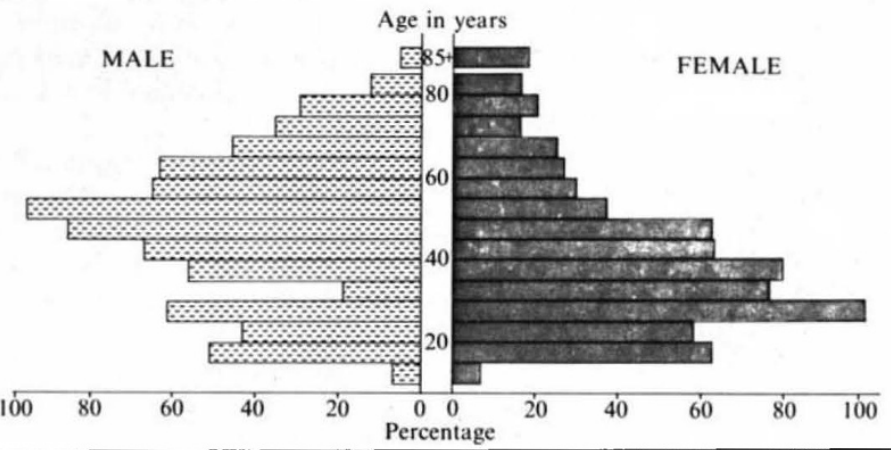

and 30 and for males between 55 and 60 . At this point the number of males registering cancer rises to almost double the number of females of the same age, a phenomenon which corresponds with, but is not explained by, a dramatic rise in the incidence of cancer of the lungs and respiratory tract in males over 50 . There is no comparative single cancer site which explains the sudden rise in the incidence of cancer in women. Source: Cancer statistics: registrations (HMSO:London, £8).

Melanie Kee 